Supplement of Saf. Nucl. Waste Disposal, 1, 193-194, 2021

https://doi.org/10.5194/sand-1-193-2021-supplement

(c) Author(s) 2021. CC BY 4.0 License.

Supplement of

\title{
Narratives and images of the future for final disposal
}

Stefanie Enderle and Peter Hocke

Correspondence to: Stefanie Enderle (stefanie.enderle@kit.edu)

The copyright of individual parts of the supplement might differ from the article licence. 
Karlsruher Institut für Technologie

safeND- Interdisciplinary research symposium on the safety of nuclear disposal practices 2021

\section{Narratives and images of the future for final diaposal}

\section{Stefanie Enderle \& Peter Hocke}

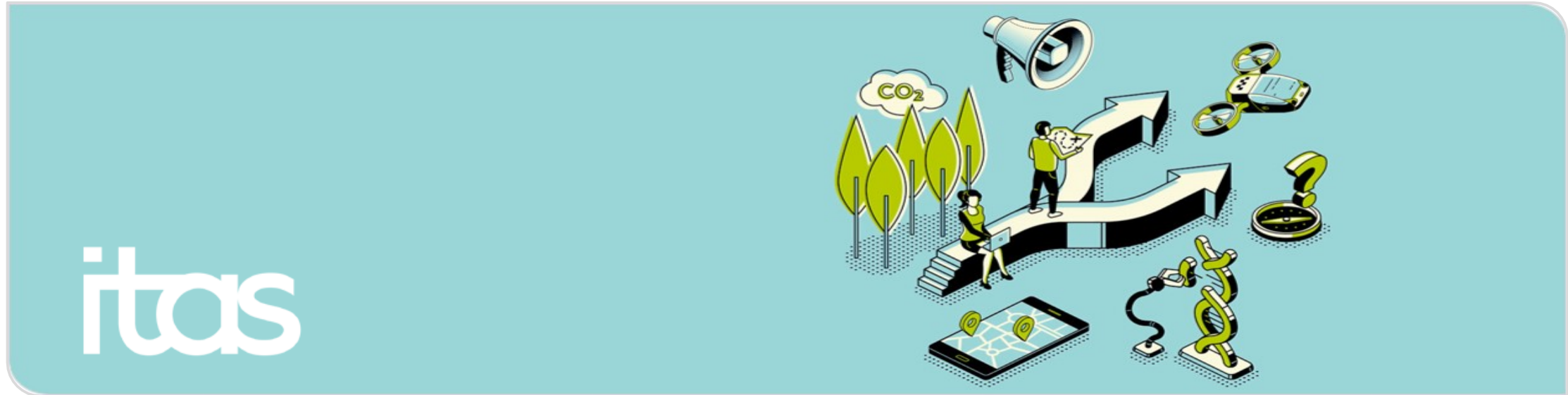




\section{Content}

1. Introduction

2. Theoretical background

3. Methodological approach

4. Empirical results

5. Conclusion 


\section{INTRODUCTION}




\section{1 „Public Participation in the Search for a Repository: challanges of an intergenerational, self-questioning and learning procedure"}

- Project partner:

- Öko-Institut e.V., Darmstadt

- team ewen GbR, Darmstadt

- Institute for Technology Assessment and Systems Analysis (ITAS)at KIT, Karlsruhe

Duration: $2018-2020$

- Funding: Federal Office for the Safety of Nuclear Waste Management (BASE) identifier 4717F00001

- Publication: Brohmann, B., Mbah, M., Schütte, S., Ewen, C., Horelt, M.-A., Hocke, P., Enderle, S.: Öffentlichkeitsbeteiligung bei der Endlagersuche: Herausforderungen eines generationenübergreifenden, selbsthinterfragenden und lernenden Verfahrens. Endbericht. Berlin, Bundesamt für die Sicherheit der kerntechnischen Entsorgung (BASE - Forschungsberichte zur Sicherheit der nuklearen Entsorgung, BASE-004/21) (urn:nbn:de:0221-2021051027029), 2021. 


\subsection{Content of the project}

- Concept for public participation, to be implemented in the sense of the Repository Site Selection Act (StandAG 2017) as a participatory, selfquestioning and learning procedure until a safe repository site is found

- ITAS WP: Narratives and future images for final disposal

- Analysis of narratives

- Evaluation of narratives and design of future images 


\section{THEORETICAL BACKGROUND}




\subsection{Narratives are...}

-... interpreted and provided with meanings

v ... unite and condense different narrative strands

- ... contain motifs, contextual conditions

- .... are temporally structured, related to the past $\&$ open to the future

- ... are not argumentative

- ... aim at authenticity

- ... are shared and taken up

(cf. Geiger 2006, Viehöver 2011, Weber 2017) 


\subsection{Images of the future - „Sociotechnical futures“}

- Perceptions, wishes and visions for aspects not yet experienced in the present.

- Technical developments and social changes are put in relation to each other.

can be different and also contrary.

- can be used to mobilize design processes.

are not only texts but can also be pictures or objects.

need arguments and explanations.

(cf. Lösch et al. 2019, Grunwald 2019) 


\section{METHODOLOGICAL APPROACH}




\subsection{From Interview to narrativ}

Qualitative guideline-assisted interviews

Experts from the fields of: science, civil society, politics, administration, companies

- Experts have "special knowledge"

- With their interpretations they structure the field of action for others

- Content-analytical evaluation of the interviews

- Elaboration of the narratives 


\subsection{From narrative to images of the future}

- Workshop with students and PhD students

- Objective 1: Reflection and further development of narratives

- Objective 2: Design of future images, based on different development paths 


\section{4. (selected) EMPIRICAL RESULTS}


4.1 Narrative: "Without Fukushima, there would be no StandAG"

- Narrative along a history of conflict

- Catastrophes have shaken confidence in nuclear energy

- The waste problem was handled in a non-transparent and politically inappropriate manner.

- Phase-out is a success of anti-nuclear movements and protests

- Reorientation of waste management policy

- Mistrust of politics and authorities due to these experiences

- Reproach: Politics acts only after disasters or massive political conflicts 


\subsection{Reflection of the narrative}

- The narrative causes many questions

- It presupposes knowledge about the past and contexts

- The past is indirectly excluded by setting a beginning with Fukushima

- Conflict history is complex and difficult to understand 


\subsection{Interim summary}

- The narrative is ambivalent

- But it occurs in discourse

- The history of conflict needs to be explained

- The success of civil society must be acknowledged

- Dissent and protest have helped to review and develop decisions 
4.4 Narrative: "The thinking in the Saint Florian principle blocks that decisions are oriented to the common interest."

- The loss of the common interest mindset strengthens NIMBY

- Emotional and fear-based arguments are also found in the discourse

- Unequal burden sharing

\subsection{Reflection of the narrative}

- Strong appeal character can lead to putting one's own concerns into perspective

- However, it also has an unempathetic effect

- Appreciation of the affected region

- Those affected are not left alone 


\subsection{Interim summary (focused on authorities): How to reflect and handle narratives}

- The company bears the project as a whole

- Risks must be communicated transparently and comprehensibly

- Emotional arguments must also be taken seriously 


\subsection{Images of the future}

- Different development path (pessimistic, moderate and optimistic)

- Action patterns of collective actors

- Government has no concept for adequate solution of the problems caused by nuclear waste

- Science has to be an independent institution (esp. basic research)

- Radwaste policy without problem-oriented foresight and without longterm strategy and governance

- Societal debate is focused on affected groups in the population

- Site selection process is dominated by protest and riots 


\section{CONCLUSION}




\section{Conclusion}

- Tension between actors with a history of conflict and "new" actors with little knowledge of the past

- Unequal burden sharing also with regard to intergenerational justice

- Narratives and images of the future can play an important role in communication process

- Sociotechnical futures can illustrate alternative courses of action and decision paths 


\section{Thank you !}




\section{References}

Brohmann, B., Mbah, M., Schütte, S., Ewen, C., Horelt, M.-A., Hocke, P., Enderle, S.: Öffentlichkeitsbeteiligung bei der Endlagersuche: Herausforderungen eines generationenübergreifenden, selbsthinterfragenden und lernenden Verfahrens. Endbericht. Berlin, Bundesamt für die Sicherheit der kerntechnischen Entsorgung (BASE - Forschungsberichte zur Sicherheit der nuklearen Entsorgung, BASE-004/21) (urn:nbn:de:0221-2021051027029), 2021.

Brown, Philip (2017): Narrative: An ontology, epistemology and methodology for pro-environmental psychology research. In: Energy Research \& Social Science 31, S. 215-222. DOI: 10.1016/j.erss.2017.06.006.

Geiger, Daniel (2006): Wissen und Narration. Der Kern des Wissensmanagements. Berlin: Schmidt.

Grunwald, Armin (2019): Shaping the Present by Creating and Reflecting Futures. In: Andreas Lösch, Armin Grunwald, Martin Meister und Ingo Schulz-Schaeffer (Hg.): Socio-technical Futures. Shaping the Present. Empirical Examples and Analytical Challenges in Social Studies of Science and Technology and Technology Assessment. Wiesbaden: Springer VS , S. 17-36.

Lösch, Andreas; Grunwald, Armin; Meister, Martin; Schulz-Schaeffer, Ingo (2019): Introduction: Socio-technical Futures Shaping the Present. In: Andreas Lösch, Armin Grunwald, Martin Meister und Ingo Schulz-Schaeffer (Hg.): Socio-technical Futures Shaping the Present. Empirical Exam-ples and Analytical Challenges. Introduction. Wiesbaden: Springer VS

Viehöver, Willy (2011): Diskurse als Narrationen. In: Reiner Keller, Andreas Hirseland, Werner Schneider und Willy Viehöver (Hg.): Handbuch sozialwissenschaftliche Diskursanalyse. Band 1: Theorien und Methoden. Wiesbaden, Opladen: VS Verl. für Sozialwiss; Leske + Budrich (Handbücher), S. 193-224.

Weber, Simon (2017): Wie Geschichten wirken - Grundzüge narrativer Psychologie. In: Jacques Chlopczyk (Hg.): Beyond Storytelling. Narrative Ansätze und die Arbeit mit Geschichten in Organisationen. Berlin, Heidelberg: Springer Gabler, S. 11-21. 